\title{
INTRODUKSI PRODUK KEFIR MULTI FUNGSIONAL KEPADA PARA PETERNAK KAMBING PERAH DI DESA BONGAN CINA SINGARAJA
}

\author{
I.N. Suparta, S.A. Lindawati, M. Hartawan, I.N.S. Miwada dan I.W. Sukanata ${ }^{1}$
}

\begin{abstract}
ABSTRAK
Tujuan pengabdian ini dilakukan adalah untuk mendukung penguatan desa bongan Cina sebagai desa penghasil susu kambing perah melalui introduksi teknologi hilir melalui metode fermentasi menjadi kefir multi fungsional. Introduksi teknologi ini dilakukan dengan metode penyuluhan dengan melibatkan para peternak kambing perah dan masyarakat lainnya yang berminat untuk mendapatkan pengetahuan. Kegiatan ini dilakukan di balai desa Bongan Cina, tanggal 11 Agustus 2017. Hasil kegiatan diawali dengan pemaparan tentang manfaat susu fermentasi kefir yang dikombinasikan dengan air kelapa sebagai sumber serat, pembuatan kefir multi fungsionali dan diikuti dengan pembagian produk kefir multi fungsional. Kelompok peternak kambing perah sangat merespon positif dengan indikator terjadi penigkatan pengetahuan hingga $100 \%$. Kefir multi fungsional ini mengandung serat $(0,71 \% \%)$, bakteri asam laktat $\left(2,57 \times 10^{5} \mathrm{CFU} / \mathrm{g}\right)$ dan berantioksidan $(116,55 \mathrm{mg} / \mathrm{L} \mathrm{GAEAC})$. Kesimpulan kegiatan bahwa multi fungsional kefir yang diintroduksikan di desa Bongan Cina memberi semangat baru bagi masyarakat dalam upaya penguatan sektor hilir usaha ternak kambing perah yang selama ini dibudidayakan.
\end{abstract}

Kata Kunci : kefir multi fungsional, serat, antioksidan

\begin{abstract}
The purpose of this dedication is to support the strengthening of Cina's bongan village as a dairy goat milk producing village through the introduction of downstream technology through fermentation method into various functional kefir. The introduction of this technology is done by extension methods involving dairy goat breeders and other people interested in gaining knowledge. This activity was carried out at the village hall of Bongan Cina village, August 11, 2017. The results of the activity started with the exposure of the benefits of fermented milk kefir combined with coconut water as a fiber source, various functional kefir production and followed by the division of various functional kefir products. Dairy goat breeders group responded positively with an indicator of up to $100 \%$ knowledge improvement. This various functional kefir contains fiber $(0.71 \% \%)$, lactic acid bacteria $(2.57 \times 105 \mathrm{CFU} / \mathrm{g})$ and be antioxidant $(116.55 \mathrm{mg} / \mathrm{L}$ GAEAC). The conclusion of the activities that the various functional kefir introduced in the village of Bongan Cina gave a new spirit for the community in an effort to strengthen the downstream sector of dairy cattle breeding business that has been cultivated.
\end{abstract}

Keywords: various functional kefir, fiber, antioxidant

\section{PENDAHULUAN}

Desa Bongan Cina terletak di ujung barat Singaraja merupakan salah satu desa yang memiliki potensi perkebunan kopi yang cukup produktif. Kegiatan para petani dalam budidaya kopi selama ini diintegrasikan dengan usaha ternak kambing perah jenis kambing PE. Selama ini, budidaya

\footnotetext{
${ }^{1}$ Staf Pengajar Fakultas Peternakank Universitas Udayana.partamas@yahoo.com
} 
kambing PE dengan produksi susu kambingnya dalam beberapa tahun terakhir menjadi ikon baru bagi desa Bongan Cina. Hasil pengamatan yang dilakukan oleh tim Unud, ditemukan beberapa kendala dalam budidaya kambing perah di desa ini, khususnya dalam pengembangan teknologi pengolahan susu kambing. Seperti diketahui bahwa susu sebagai produk hasil ternak yang kaya protein dan berpotensi tinggi untuk cepat terjadinya pembusukan jika tidak dilakukan penanganan pasca panen. Oleh karena itu, pentingnya introduksi teknologi pengolahan susu kambing dengan memanfaat potensi lainnya yang ada di desa ini, yakni penggunan air kelapa dan dikombinasikan serta diterapkan teknologi fermentasi dengan menggunakan bibit kefir sehingga dihasilkan produk kefir multi fungsional. Teknologi fermentasi merupakan strategi pengolahan susu yang menghasilkan produk fungsional (Suparta et al., 2015).

Introduksi teknologi yang dilakukan di desa Bongan Cina dilakukan sebagai tahap awal untuk menggugah kesadaran masyarakat tentang pentingnya mengkonsumsi susu fermentasi dan pada akhirnya ada minat yang kuat untuk pengolahan susu kambing melalui metode fermentasi. Seperti diketahui, produk susu fermentasi tersebut beranekaragam jenisnya, diantaranya dikenal produk kefir yang mengandung antioksidan (Suparta et al., 2017). Miwada et al. (2011) menyebutkan bahwa adanya bakteri asam laktat (BAL) pada produk susu fermentasi akan menguatkan lagi sifat fungsionalnya sehingga sangat sangat dibutuhkan untuk kesehatan tubuh. Tujuan kegiatan pengabdian ini adalah introduksi teknologi hilir kepada masyarakat di desa Bongan Cina tentang produk kefir multi fungsional dan sekaligus menguatkan kembali upaya pengembangan budidaya kambing perah sehingga memberikan nilai tambah ekonomi dan sekaligus membantu meningkatkan kesehatan masyarakat.

\section{METODE PELAKSANAAN}

Introduksi kefir multi fungsional kepada masyarakat desa Bongan Cina, Singaraja dilakukan pada tanggal 11 Agustus 2017. Kegiatan dilakukan di Balai Desa Bongan Cina. Kegiatan ini melibatkan para peternak kambing perah, ibu-ibu peternak, pemuda desa dan masyarakat lainnya yang tertarik untuk meningkatkan pengetahuannya. Kegiatan ini diinisiasi oleh tim Unud khususnya dari staf dosen di Lab. Teknologi dan Mikrobiologi Hasil Ternak dan Lab. Sosek Fakultas Peternakan Unud. Metode kegiatan pengabdian ini dilakukan dengan metode penyuluhan dan diikuti dengan diskusi serta evaluasi akhir untuk mengukur tingkat capaian yang dihasilkan. Kegiatan ini sendiri merupakan sub kegiatan dari program kegiatan IbIKK (Ipteks bagi Inovasi dan Kreativitas Kampus) dengan mengembangkan upaya kemitraan pada masyarakat pelaku usaha budidaya ternak kambing perah di desa Bongan Cina.

\section{HASIL DAN PEMBAHASAN}

Introduksi produk kefir berserat di kalangan para peternak kambing perah di desa Bongan Cina, Singaraja diawali dengan pemaparan dan harapan dari Kepala Desa Bongan Cina (I Gusti Nyoman Putu Adnyana). Disebutkan bahwa Desa Bongan Cina, dulunya dikenal sebagai salah satu penghasil susu kambing perah di Bali. Potensi desa yang memungkinkan untuk tumbuh dan berkembangnya budidaya kambing perah ini harus diikuti dengan penguatan ipteks sehingga memberikan peningkatan kesejahteraan bagi peternak dan masyarakat Desa Bongan Cina. Oleh karena itu, tim pengabdian Unud menyambut positif harapan dari masyarakat yang disampaikan oleh kepala desa Bongan Cina tersebut. Salah satu penguatan ipteks yang disosialisasikan pada kegiatan pengabdian ini yakni introduksi penguatan teknologi pasca panen khususnya teknologi fermentasi susu kambing dengan inokulasi bibit kefir sehingga menghasilkan produk kefir. Potensi lainnya yang cukup menarik untuk dikolaborasikan dengan produksi kefir ini yakni penggunaan air kelapa sebagai sumber serat. Di desa ini, disamping budidaya kambing perah juga ada budidaya pohon kelapa dan potensi

\section{0 | BULETIN UDAYANA MENGABDI}


air kelapanya bisa memberi karakteristik khas dari kefir susu kambing. Lebih lanjut tim pengabdian Unud juga menjelaskan bahwa kefir susu kambing dengan karakteristik berserat menghasilkan produk kefir yang multi fungsional. Potensi multi fungsional tersebut diantaranya produk kefir mengandung anti bakteri, antioksidan dan berserat. Hasil Kajian secara lengkap dapat disajikan pada Tabel 1.

Tabel 1. Karakteristik Kefir Multi Fungsiona dari Penambahan Air Kelapa

\begin{tabular}{|l|c|}
\hline \multicolumn{1}{|c|}{ Indikator Pengukuran } & Total \\
\hline Serat (\%bb) & 0,71 \\
\hline Tanin (mg/100 gr GAE) & 32,75 \\
\hline Antioksidan (mg/L GAEAC) & 116,55 \\
\hline Protein (\%bb) & 4,82 \\
\hline Lemak (\%bk) & 3,62 \\
\hline Laktosa (\%) & 4,37 \\
\hline Bakteri asam laktat (CFU/gr) & $2,57 \times 10^{5}$ \\
\hline Warna (skor) & 3 \\
\hline Citarasa (skor) & 4 \\
\hline
\end{tabular}

Keterangan :

GAEAC : Gallic Acid Equivalent Antioxidant Capacity

GAE : Gallic Acid Equivalent

Introduksi kefir multi fungsional yang disosialisasikan kepada para ibu-ibu peternak di desa Bongan Cina ini merupakan hasil keberlanjutan dari kajian penguatan sifat fungsional pada produk kefir tersebut. Seperti pada Tabel 1, karakteristik produk susu fermentasi kefir ini tidak berbeda jauh dengan yang dilaporkan oleh Suparta et al. (2015) dan (2017). Bahkan hasil kajian dari produk yang disosialisasikan di desa Bongan Cina memiliki kualitas yang lebih lengkap, khususnya dalam potensi serat, antioksidan dan berprobiotik. Potensi probiotik pada produk ini didominasi oleh Bakteri Asam Laktat (BAL) sehingga menambah sempurna kualitas produk yang diintroduksikan di desa Bongan Cina. Miwada et al. (2011) menyebutkan bahwa BAL yaitu mikroorganisme non patogen yang sangat dibutuhkan untuk kesehatan tubuh dan keberadaannya sangat dominan pada produk susu fermentasi. Karakteristik penampilan produk yang diintroduksikan di desa Bongan Cina seperti pada gambar 1 dan penampilan dalam bentuk yang sederhana seperti pada gambar 2 .

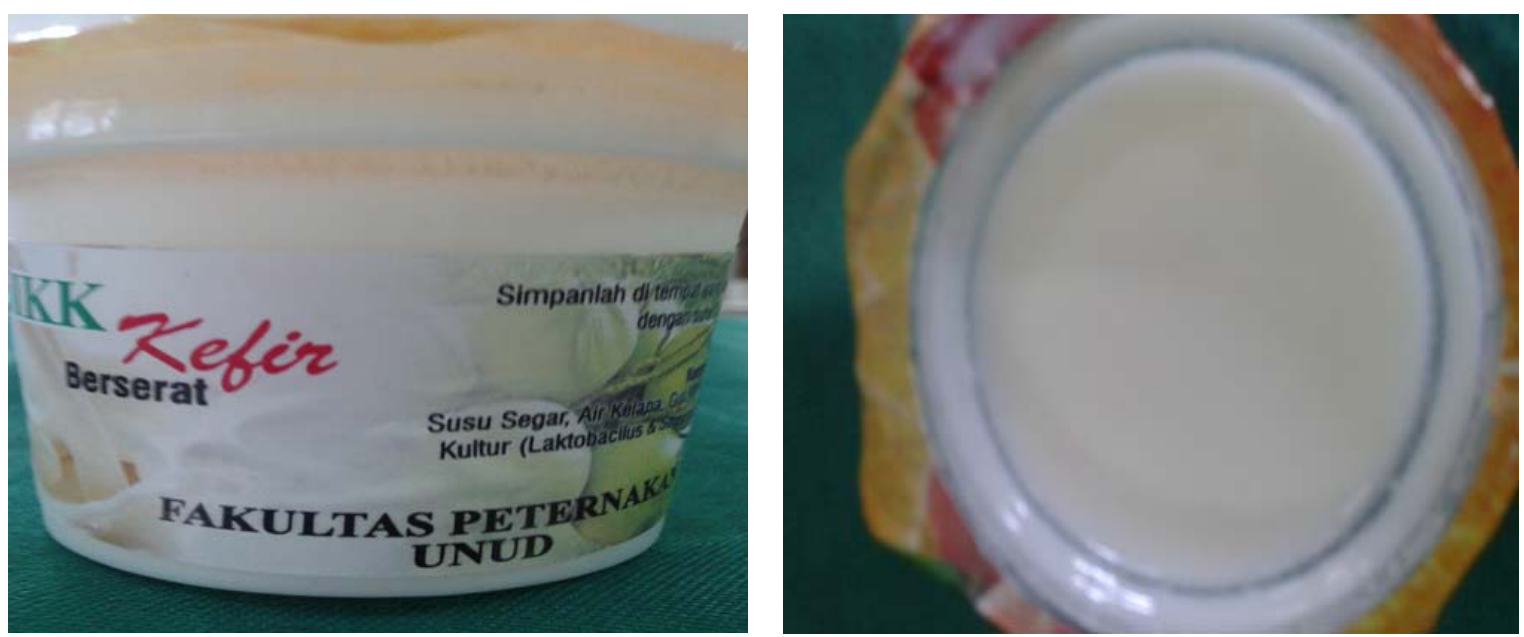

Gambar 1. Produk Kefir Berserat yang Dintroduksi pada Masyarakat di Desa Bongan Cina 
Kegiatan pengembangan atraksi wisata edukasi sapi bali merupakan konsep lainnya yang dikembangkan dalam upaya menjaga eksistensi sapi bali. Pada kesempatan tersebut juga dihadiri oleh beberapa wisatawan mancanegara, seperti Yoko Kiyoshima, dan Ikuyo Tabata yang keduanya asal Jepang serta Bella Delannoy dan Natasha Belevska asal Belgia (gambar 3). Para wisatawan yang hadir pada kegiatan atraksi ini sangat senang dengan model atraksi edukasi wisata sapi bali ini. Bahkan mereka baru tahu bahwa sapi bali itu sebagai plasmanuftah Indonesia yang keasliannya hanya di Pulau Bali. Disamping itu, Kepala desa Sobangan (Ketut Mas Budiartha, SH) sangat mengapresiasi gagasan yang dilakukan oleh mahasiswa KKN dan berharap Pemda Badung bisa membantu membantu kelancaran program yang telah digagas.
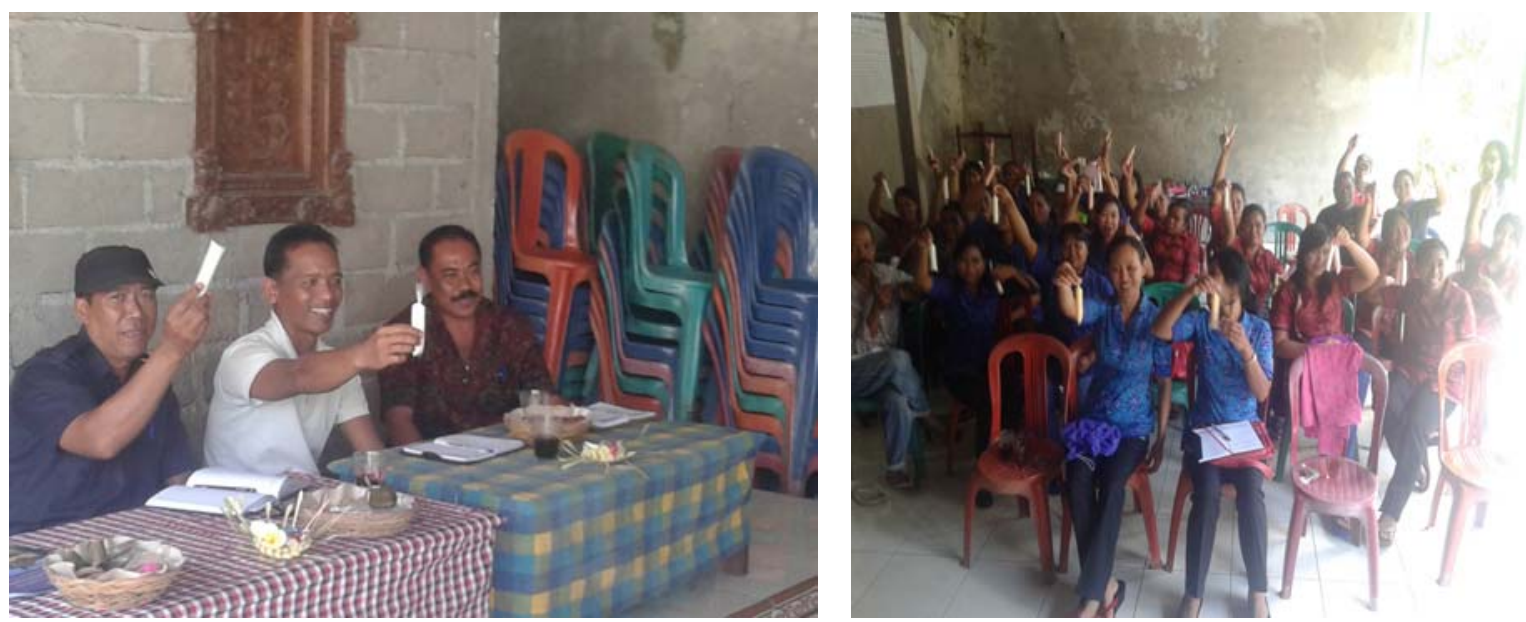

Gambar 2. Respon Masyarakat Desa Bongan Cina Cukup Antusias dengan Produk Kefir Berserat

Secara keseluruhan respon peserta di desa Bongan Cina sangat antusias. Hasil evaluasi kegiatan terungkap bahwa di desa ini ternyata hanya $10 \%$ dari 27 peserta yang hadir pernah mendengar dan merasakan produk susu fermentasi namun hampir $100 \%$ peserta belum pernah merasakan produk kefir dengan potensi multi fungsional. Faktor pendorong keberlanjutan kegiatan ini yakni adanya potensi masyarakat desa Bongan Cina dengan profesi sebagai peternak kambing perah akan menjamin pengetahuan yang diperoleh bisa dimultifikasikan untuk mendukung nilai tambah usahanya. Faktor penghambat yang mungkin perlu disolusikan adalah inovasi pemasaran produk serta sosialisasi pada masyarakat umum (yang ada di sekitaran desa Bongan Cina) tentang pentingnya mengkonsumsi susu fermentasi sehingga akan meningkatkan animo kebutuhan masyarakat.

\section{SIMPULAN DAN SARAN}

Introduksi produk kefir multi fungsional yang dilakukan di Desa Bongan Cina telah memberikan peluang baru bagi masyarakat desa Bongan Cina, khususnya para peternak kambing perah (penguatan ipteks peternak mencapai 100\%). Kefir multi fungsional yang diperkenalkan mengandung komposisi seperti serat $(0,71 \% \%)$, bakteri asam laktat $(2,57 \mathrm{x}$ $\left.10^{5} \mathrm{CFU} / \mathrm{g}\right)$ dan berantioksidan (116,55 mg/L GAEAC).

Desa Bongan Cina dengan potensi budidaya kambing perahnya selama ini perlu didorong secara terus menerus untuk dikembangkan melalui konsep hulu hingga hilir sehingga nilai manfaatnya bisa lebih optimal bisa dirasakan. 


\section{UCAPAN TERIMAKASIH}

Kegiatan pengabdian ini terlaksana sebagai bagian dari kegiatan inovasi dan kreativitas kampus melalui Hibah Pengabdian IbIKK Dikti. Oleh karena itu, penulis mengucapkan terima kasih kepada Direktorat Riset dan Pengabdian kepada Masyarakat Direktorat Jenderal Penguatan Riset dan Pengembangan Kementerian Riset, Teknologi dan Pendidikan Tinggi Sesuai dengan Surat Perjanjian Penugasan Pelaksanaan Pengabdian kepada Masyarakat Nomor : 416.5/UN14.4.A/PM/2017, Tanggal 30 Maret 2017

\section{DAFTAR PUSTAKA}

Miwada, IN.S., S.A. Lindawati, M. Hartawan, IN.S. Sutama, IN.T. Ariana dan IP.Tegik. 2011. Evaluation of The Capabilities of Various Local Bamboo as The Palces of Milk Fermentation without Inoculant of Lactic Acid Bacteria. Animal Production 13(3): 180-184.

Suparta IN, S.A. Lindawati, IW.Sukanata, IN.S.Miwada dan M. Hartawan.2015. Introduksi Produk Susu Fermentasi "Kefir" dan Strategi Pemasaranya di Lingkungan Kampus Unud Denpasar. Jurnal Udayana Mengabdi 14(2) : 64-66

Suparta IN, S.A. Lindawati, IW.Sukanata, IN.S.Miwada dan M. Hartawan.2017. Sosialisasi Potensi Susu Fermentasi bagi Masyarakat di Desa Pempatan Karangasem dan Upaya Pengembangannya Berbasis Potensi Lokal. Buletin Udayana Mengabdi 16(2) : 16-20 